\title{
Clough, Emerson, and Knowingness
}

\begin{abstract}
The poetry of Arthur Hugh Clough has tended to be read in dialogue with the writings of his friend and critic, Matthew Arnold. This essay explores how bringing Clough's work into conversation with that of a very different friend, Ralph Waldo Emerson, offers to cast his intellectual affinities and poetic technique in a new light. Interweaving close readings of Clough's verse with detailed attention to the essays he is known to have read and admired, I trace how Clough adapts and revises Emerson's critique of 'knowingness'. Beginning by tracing the history of this term in nineteenth-century literature and culture, I argue that Clough's Dipsychus shapes an Emersonian ethic and aesthetic of encounter as an alternative to complacent and proprietorial forms of knowing. Turning to the rest of Clough's oeuvre, especially Amours de Voyage, I then consider how fantasies of the future are central to what it means to be knowing about oneself, and examine how Clough applies poetic pressure to Emerson's conviction that 'A man ... never rises so high as when he knows not whither he is going'.
\end{abstract}


'[T]he disease of our time is its smartness, cleverness - that hellish New England hunger to know something.'

$$
\text { Walt Whitman }{ }^{1}
$$

In his essay 'Montaigne, or the Skeptic', Ralph Waldo Emerson closes in on a kind of cloistered conceitedness: “"Ah," said my languid gentleman at Oxford, "there's nothing new, or true,- - and no matter.",2 Emerson's Oxonian stooge has his genesis in a note of 1848 , made during Emerson's first visit to the city at the invitation of a young Fellow and aspiring poet, Arthur Hugh Clough. Curiously, Emerson attributes the remark in his journal to a ‘country gentleman' - perhaps one of his Oxford acquaintances had repeated it to him with this attribution and he later decided it was more characteristic of the teller. In any case, Emerson's essay on Montaigne appears to have its roots in this Oxford excursion, for it was shortly afterwards that he acquired his own copy of the Essays. ${ }^{3}$ By an intriguing symmetry, two weeks before he began work on Dipsychus and the Spirit, Clough wrote to Emerson to thank him for a copy of Representative Men, the collection to which the essay on Montaigne belongs. ${ }^{4}$ This essay seems to have been much on Clough's mind at the time, since he co-opts the very words of Emerson's gentleman ('And nothing's new and nothing's true') for the jaunty counsel of despair which haunts Dipsychus in a dream. ${ }^{5}$ Taking off from this circle of allusions, I want to suggest that Clough's most elusive of poems owes a profound debt to Emerson's essays, and to argue more broadly that Clough's poetry is animated by a resistance to the outlook of Emerson's languid Oxonian. The attitude that expresses itself in these terms is the one Emerson elsewhere called 'knowingness': the supercilious confidence in what one already knows, the complacent assumption that there is nothing else to know, the overattachment to knowing as a means of orienting oneself towards the world. ${ }^{6}$ 
Emerson's interrogation of knowingness, then, puts in question a certain disposition, rather than erudition. Consider the winking insinuations of the dream-voice, which make knowing a matter of experience rather than learning: 'You should have gone at least to college, / And got a little ampler knowledge' (1. 7. 39-40). The strain of 'knowingness' that these lines articulate is that which one Victorian commentator censured in contemporary music-hall, an affair of 'innuendoes', 'self-conceit', and 'shallow wit'. ${ }^{7}$ This rather po-faced portrayal is indebted to Hazlitt's 1823 portrait of the cockney, condemned for his 'ground of native shallowness mounted with pertness and conceit', which forms 'that knowing character which he so much affects'. ${ }^{8}$ The evolution in usage of the adjective 'knowing'—often held at an ironic distance in the period by the use of inverted commas or italics - testifies to the significant cultural currency which this attitude acquired over the nineteenth century. Early on it had signified familiarity with the secrets of the turf, and by extension an eye for fashion (as in the 'very knowing gigs' glanced at in Sense and Sensibility). ${ }^{9}$ As the century progressed, however, it took on an increasingly satirical edge, and is almost always wielded to comic effect by Dickens and Thackeray, in whose hands it batters the pretensions of the workhouse Board, Miss Mowcher, Pendennis, and many besides. ${ }^{10}$ It is this very knowing deployment of the rhetoric of knowingness to which Edith Hall refers when she observes that, in the nineteenth century, "those who used the term "knowingness" or its cognates in a tone of disparagement were invariably asserting a position of superiority in class, taste and actual education'. ${ }^{11}$

And yet this is only half the story, as a sentence from one of George Eliot's letters suggests: 'If there is one attitude more odious to me than any other of the many attitudes of "Knowingness", she wrote, 'it is that air of lofty superiority to the vulgar.' ${ }^{12}$ Similarly, Thomas Carlyle had the intellectuals rather than the masses in his sights when he repeatedly inveighed against 'the vulpine intellect, with its knowingness', a quality he elided with 
'Scepticism' and 'lofty self-complacency'. ${ }^{13}$ Bridging these two broad characterizations of knowingness was the contemporaneous emergence of the term 'know-it-all', which the $O E D$ traces to 1849 , along with the associated phrase 'to think one knows it all' - 'to have an inflated idea of one's knowledge, wisdom, expertise ... to be oblivious to one's deficiencies'—which it dates to $1857 .{ }^{14}$ These mid-century developments in the language gave broader cultural traction to a phenomenon previously associated with the rather recherché term 'sciolist' ('A person whose knowledge is only superficial, esp. one who makes much of it'). ${ }^{15}$ In his journal for 1853-1854, Emerson identified this term with a refrain similar to that of his Oxford man: 'The young sciolist', he wrote, 'learns to say what is true in this is not new, \& what is new is not true. ${ }^{, 16}$ While Emerson's sciolist is distinguished from his Oxonian by admitting the possibility of novelty and truth, both figures root their identity in their superior knowledge even as their capacity for knowing has dwindled into a clutch of rhetorical and psychological reflexes. It is this mindset that Clough's dream-voice inhabits, and he has mastered its Victorian repertoire: for if he struts with music-hall swagger, he also strikes a philosophical tone with his dismissals of love, justice, and even pleasure as the delusions of inferior minds: 'O piddling merchant justice go, / Exacter rules than yours we know' (1. 7. 99-100). The dream-voice's 'we' invokes an imagined community, indeed an aristocracy, of knowers, inviting the listening Dipsychus into the collusive ranks of those supposedly in the know.

These characterological definitions of knowingness are supplemented in the period by Coleridge's suggestive account of it as a form of literary affect. In his lecture notes on Sterne, Coleridge censured 'A sort of knowingness the wit of which depends $1^{\text {st }}$ on the modesty, it gives pain to; or $2^{\text {ndly }}$ the innocence $\&$ innocent ignorance over which it triumphs; or 3. on a certain oscillation in the individual's own mind between the remaining Good and the encroaching Evil of his nature, a sort of dallying with the Devil'. ${ }^{17}$ Just such an oscillation is 
the subject of Clough's bedevilled verse-drama, whose 'two-souled' hero pre-empts his own 1853 call for a poetry 'in all points tempted as we are'. ${ }^{18}$ Unlike Faust, which pursues the consequences of its protagonist's submission to the temptation of knowledge, Clough's poem is a protracted dalliance with knowingness in various forms. Coleridge's further suggestion that knowingness has to do with immodesty anticipates Emerson's critique of 'impudent knowingness' in his essay 'Experience' - a phrase whose sexual connotations are exfoliated by his subsequent observation that 'The art of life has a pudency, and will not be exposed' (40). As Richard Poirier has glossed this passage, such knowingness, 'resentful of anything it cannot explain ... exposes the genitalia, as if, by pointing to this or that or any other single organ, it could explain desire or the productivity of mind' ${ }^{19}$ Alexis de Tocqueville regarded this fault as a peculiarly American one: 'they readily conclude', he wrote in 1840, 'that everything in the world can be explained and that nothing surpasses the limits of intelligence'. ${ }^{20}$ In similar vein, Clough's college friend John Campbell Shairp deplored the 'too great knowingness' of the Whiggish historiography on which his generation had been reared: with such chroniclers 'the most complex characters are explained down to the ground', he complained, and 'when they have said their say, there remains no more behind' ${ }^{21}$ By contrast, Emerson asserts that, for each man, 'The last chamber, the last closet, he must feel, was never opened; there is always a residuum unknown'. ${ }^{22}$ In a culture saturated with knowingness, Clough and Emerson repeatedly pressed the claims of this residuum. 'Let there be Priests, if you please, to preserve the known', Clough confided to his notebook as he was composing the first drafts of Dipsychus; 'But there shall also be Priests to vindicate the unknown.'23

Reading Clough alongside Emerson encourages us to see his poems' characteristic unsettledness as something other than the melancholy music of someone who 'felt more than most men the weight of the unintelligible world', as his student Walter Bagehot would later 
write of him. ${ }^{24}$ Isobel Armstrong has observed that Matthew Arnold's portrait of Clough as Thyrsis, the shattered shepherd-poet, set the tone for Clough's critical reception throughout the nineteenth century and beyond: witness John Addington Symonds' digest of the poems as 'the waverings of a discontented spirit ill at ease', or George Saintsbury's uncharitable portrait of their author as one 'with neither the strength to believe nor the courage to disbelieve'. ${ }^{25}$ Restoring Emerson to the frame offers to reset the balance, and is no less inviting when one reflects that the connections between their work remain conspicuously underexplored. Only Paul Giles and Adam Phillips, who persuasively identify Emerson as an interlocutor in Amours de Voyage, have taken up Evelyn Greenberger's suggestion, now nearly 50 years old, that the evidence 'warrants more sustained attention and interpretation than it has hitherto received' and 'may yield further insight into a turbulent period in Clough's life and writings'. ${ }^{26}$ Given that Clough's poetic output is largely concentrated during those years in which his friendship with Emerson was most intense-roughly 1848 to 1854-Greenberger perhaps even understates the case. Clough's bicentenary seems an opportune moment to reopen inquiries. ${ }^{27}$

Emerson's concept of knowingness also provides a new point of reference for wider critical discussion about Clough's intellectual bearings, which in recent years has tended to construe his poetry as an arena for testing the strength of 'scepticism' against various contemporary ideals: the 'spiritual optimism' of the New World (Paul Giles) or the 'sincerity' and 'commitment' of republican duty (Anna Barton). ${ }^{28}$ Unlike scepticism, knowingness denotes neither a method nor a philosophical position, but rather a particular manner of holding a position. It therefore has affinities with the quality of mind Clough called 'positiveness', which Gregory Tate paraphrases as 'moral and intellectual overconfidence'.29 Emerson's term, however, is perhaps the more versatile, both because it suggests how this attitude might involve a travesty of knowing and because it avoids the impression that such 
overconfidence is always in the interest of assertion rather than denial; while Tate pitches Clough's 'irrepressible scepticism' against the perceived threat of 'positiveness', Emerson will suggest how scepticism itself might manifest as knowingness. ${ }^{30}$ Angling a critical lens on the phenomenon of Victorian knowingness, then, provides a way of rethinking Clough's intellectual affiliations, offering a new perspective on his poetic technique while building a fuller picture of the transatlantic traffic in ideas in the mid-nineteenth century.

\section{DANGEROUS TO KNOW}

Having devoured Emerson's essays as a student, Clough later secured an introduction through family friends and in late 1847 invited him to Oxford, an offer which Emerson took up the following spring. Within six months of that visit, Clough had quitted his fellowship of Oriel College - a shocking, principled resignation from an essentially religious institution that mirrored Emerson's own abandonment of his ministry in the Unitarian Church at the very same age of twenty-nine. ${ }^{31}$ The pair maintained a close friendship, Clough admitting that he had 'largely learnt' from Emerson, and Emerson avowing that Clough 'interested me more than any other companion' ${ }^{32}$ Clough even joined Emerson in America for a time in the early 1850 s, intent on a new life in the country of his early youth, but he returned to England in 1853 and married Blanche Smith the following year. ${ }^{33}$

The relationship between Emerson and Clough is perhaps best conceived less as a question of 'influence' (what, after all, could be less Emersonian than emulation?) than of tenacious attention and friendly provocation, in both directions. Another passage in Emerson's journals from 1848 — a year in which he and Clough kept daily company for a month in Revolutionary Paris ahead of a further two months of close contact during Emerson's English lecture tour-describes a rapport sustained by companionable 
independence of mind. ${ }^{34}$ ' 'Tis, I think, the most real benefit I have had from my English visit, this genius of Clough', Emerson wrote. 'I found him the best pièce de resistance, \& tough adherence, that one could desire. ${ }^{35}$ Adherence, rather than adherent, because what Emerson admires is Clough's ability to grasp ideas, not merely nod along - a tactility of mind suggested by this passage's other terms of approbation, 'tenacity' and 'apprehensiveness' ${ }^{36}$ Emerson's Gallicism, meanwhile, carries not only the redundant sense of something superlative but, more importantly, the ideas of strength and endurance conveyed by the French phrase de résistance, meanings which bring it into parallel with 'tough adherence'. ${ }^{37}$ And yet it is also shaded by the other meaning of resistance as opposition, and both senses are operative on those occasions Emerson names 'resistance' as an attribute of genius. 'The Over-Soul', from the 1841 series of essays which Clough read in five days shortly after graduating, hails those who 'must always be a godsend to princes, for they confront them, a king to a king, without ducking or concession, and give a high nature the refreshment and satisfaction of resistance'. ${ }^{38}$ Emerson returns to the theme in the later essay 'Character', describing the 'ingenious' man as a 'goad' who, instead of dispensing 'nimble pieces of benevolence and etiquette ... shall stand stoutly in his place, and let me apprehend, if it were only his resistance' - a process which procures 'great refreshment for both of us'. ${ }^{39}$ Rather than hypostatizing genius into an essence, Emerson conceives it as a power that manifests itself in encounter. In Clough's poetry, insisting on such an ethic and aesthetic of encounter becomes a powerful means of contending against knowingness.

Dilemmas of encounter-'What are we to resist, and what are we to be friend with?', as Clough puts it in The Bothie of Tober-na-Vuolich — power the drama of Dipsychus, taking their cue in part from Emerson's essay on Montaigne. ${ }^{40}$ Dipsychus not only asks the same questions which Emerson raises in that essay—-the 'Why? and Whereto?' of religious belief, and of social arrangements like marriage and the market economy (85) — it also shares its 
dialectical method of interrogating these questions. Emerson frames his discussion like this: 'Shall the young man aim at a leading part in law, in politics, in trade? It will not be pretended that a success in either of these kinds is quite coincident with what is best and inmost in his mind. Shall he, then, cutting the stays that hold him fast to the social state, put out to sea with no guidance but his genius? There is much to say on both sides' (90). In 1850 such questions were far from academic for Clough. He was agonizing over political and economic problems, not least those presented by his experience in the short-lived Roman Republic. And if he had hoped that London's nonconformist University Hall would offer a refuge from the sectarianism which poisoned Oxford for him, he had been sadly undeceived — as he wrote to Tom Arnold in late 1849, 'I have no confidence in my own tenure. For intolerance, O Tom, is not confined to the cloisters of Oxford or the pews of the establishment, but comes up like the tender herb— partout. ${ }^{, 41} \mathrm{He}$ had turned 30, and was wondering more urgently than ever what to do with his life - the 'Why? and Whereto?' of it all.

Emerson structures these questions as a missed encounter between two versions of knowingness, which he dubs the 'materialist' and the 'abstractionist' respectively (88). It is a structure which echoes that of Emerson's 1841 lecture, 'The Transcendentalist', which located similarly antagonistic tendencies within the same, self-divided mind: 'The worst feature of this double consciousness,' Emerson proclaimed, 'is, that the two lives, of the understanding and of the soul, which we lead, really show very little relation to each other, never meet and measure each other: one prevails now, all buzz and din; and the other prevails then, all infinitude and paradise' ${ }^{42}$ Dipsychus brings Emerson's fantasy of a double consciousness to life, availing itself of the more dramatic construction of the later essay while hinting that the alternative types there delineated may exist in the same person ('Myself or not myself?' Dipsychus wonders of the Spirit (1.2.19)). 
The first party identified in 'Montaigne' are the men of 'talent and action', conversant with 'facts and surfaces; cities and persons' (85). Emerson's paratactic briskness mimics the superficial orderliness of a mind for whom persons are blithely interchangeable with places. The worldly-minded Spirit who shadows Dipsychus expresses himself in similarly ship-shape fashion: everything fits neatly together in his hudibrastic couplets as in his worldview. Like Emerson's materialists, the Spirit takes for granted the authority of a common standard conceived in the thinnest of terms - his 'stock of knowledge' (2. 5.143) is a hoard of 'facts' (2. 4. 115) and 'common sense' (2. 3. 175). Yet if he defers to common knowledge the Spirit also enjoys a more collusive sense of knowingness in rhymes like 'piety' / 'society' (1. 4. 101-2) and 'robbing' / 'stock-jobbing' (1. 5. 166-7). Fashioning himself as one who simultaneously sees through and exploits prevailing pieties, there is an irony about the Spirit's name that is entirely apt. In early drafts, however, Clough called him 'Mephistopheles', and he bears a striking resemblance to Goethe's version of this character as evoked by Emerson in another essay from Representative Men, 'Goethe, or the Writer' ${ }^{43}$ Like Goethe's tempter, Clough's Spirit has been 'stripped of mythologic gear' and made to sound like a 'gentleman': he is 'real', 'modern', and 'European', with his 'savoir-vivre, savoir-faire' (2. 2. 72). ${ }^{44}$ Emerson's Mephistopheles is heavily indebted to Carlyle, who represented Goethe's character as a diabolical knower, 'the Devil, not of Superstition, but of Knowledge'. Puffed up with 'self-conceit' about his 'shrewd, all-informed intellect', Carlyle's Mephistopheles_-like Clough's Spirit—is blind to the narrowness of his knowledge. ${ }^{45}$

Carlyle's antipathy to knowingness maps out the terrain which Emerson was to claim for his own in 'Experience', from his Second Series of 1844 which Clough commended to his sister Anne. ${ }^{46}$ Among Emerson's targets in this essay are physicians and phrenologists who profess to draw up the 'inventory' of a man's 'fortunes and character' by 'such cheap 
signboards as the color of his beard, or the slope of his occiput', and it is in this context that he memorably concludes, 'The grossest ignorance does not disgust like this impudent knowingness' (31). In this passage, Emerson explicitly aligns knowingness with 'materialists' (31), the same class he rebukes in 'Montaigne' as those who 'make themselves merry with the philosopher, and weigh man by the pound' (87). Such downright, no-nonsense types 'believe that mustard bites the tongue' and that 'there is much sentiment in a chest of tea' (87). Clough's Spirit appears to be of this party: 'This is what comes of drinking tea', he sneers when Dipsychus turns lyrical about resisting his enticements (1. 6. 32).

The Spirit's distinguishing characteristic, however, like that of Emerson's Mephistopheles, is his recruitment of 'intellect' to 'the service of the senses' (87), evident in his witty dismissal of philosophical idealism: 'These juicy meats, this flashing wine, / May be an unreal mere appearance; / Only_-for my inside, in fine, / They have a singular coherence' (1. 5. 76-9). Coherence, mimed here in the Spirit's feminine rhyme, is a quality about which Clough's poem persistently encourages suspicion. The Spirit imposes coherence through the levelling effect of his cynicism, which interprets everything as a product of (or an opportunity for) self-seeking. His ruthlessly reductive theory of human motives derives part of its appeal from its deconstructive verve, the way it makes friends of apparently contradictory phenomena: describing himself as 'This compound of convention and impiety, / This mongrel of uncleanness and propriety' (2. 5. 49-50), he allows rhythm and rhyme to break apart the chiastic structure of his sense and fetch out hidden correspondences ('convention' / 'uncleanness', 'impiety' / 'propriety').

The Spirit's tactics foster a dynamic of knowingness akin to that evoked by Coleridge: a 'dallying with the Devil ... so that the mind has in its own white \& black angel the same or similar amusements as might be supposed to take place between an old Debauchee and a Prude — resentment from the prudential anxiety to preserve appearances, \& 
have a character, and an inward sympathy with the Enemy'. ${ }^{47}$ Simultaneously debunking and delighting in the stage-play of appearances, Clough's Spirit tunes the form as well as the substance of his speeches so as to invite collusion in his debaucheries. Meanwhile Dipsychus, worried about 'the good word / Of fellow men' and 'sanction of the law' (1. 3. 207-8), supplies the amusement of Coleridge's prude with his self-titillating portrait of the prostitute, his own rhetoric acting like the very 'pawey fingers' he condemns (1.3.110): 'The ripe lips paled, the frolick pulses stilled, / The quick eye dead, the once fair flushing cheek / Flaccid under its paint; the once heaving bosom-' (1.3. 106-8).

Yet there is another, graver aspect to Dipsychus's parrying of the Spirit: his Platonic yearning to escape material conditions altogether. As the Spirit scornfully puts it, Dipsychus attempts to 'Live in metaphysic' (2.5.154), regarding any active role he might take in life as fatally corrupt and corrupting, leaving only the non-option of 'abstaining' (1. 5. 52): 'Oh, could I shoot my thought up to the sky, / A column of pure shape', he yearns (2. 3. 140-1). Sexualized imagery notwithstanding, this Dipsychus turns out to be less like Coleridge's libidinous prude than one of Emerson's 'abstractionists', who decry all those 'who are not devoted to their own shining abstractions' as 'monsters' (86). Indeed, it is because he is unable to conceive of participation in the world except via the trope of sexual knowledge that Dipsychus attempts to barricade himself against experience, casting the Spirit as a 'filthy Belial' (1. 3. 24). The abstractions to which Dipsychus is devoted twinkle inaccessibly overhead, so abstract they are scarcely named except in the circular language of purity: 'Clear stars above ... / Take up my being into yours; assume / My sense to know you only; steep my brain / In your essential purity' (1. 2. 51-4). Longing to be assumed into a heaven of abstraction, to exchange being for pure knowing, Dipsychus's desire for 'essential purity' slides between a visceral horror of worldly corruption and an impossible demand for certainty: he refuses in one breath to "call the unstable sure / The unlovely lovely and the 
filthy pure' (1. 5. 65-6). Praying to be left alone to 'know my knowledge to the world unknown' (1.5.83), this Dipsychus is a study in knowingness of a more exclusive and precipitous order than that envisaged by Coleridge — as if the only thing one could do with one's knowledge were to know it, and as though such knowledge, 'my knowledge', were private property. If for a moment it sounds like knowing is something Dipsychus might $d o$ 'to the world', this possibility is peered at only to be foreclosed by 'unknown', whose own ambiguity of reference suggests both that Dipsychus's knowledge is unknown and that, by remaining unknown himself, he intends to keep it that way.

Stanley Cavell, most Emersonian of philosophers, sheds further light on Dipsychus's brand of knowingness with his portrayal of the post-Cartesian sceptic, whom he characterizes as 'the thinker wishing to bring assertion to its greatest fastidiousness, refusing our knowledge as of the world, so refusing the world, because he cannot satisfy our apparently pure demand for certainty, or demand for pure certainty'. ${ }^{48}$ This overweening will to knowledge finds an echo in Dipsychus's lament that the world in which he finds himself does not match up to the 'true world which our reason knew' (1.3. 7), his baffled quest for 'purity', 'perfection', and 'permanence' (1. 2. 54, 1. 5. 52, 1. 3. 209). Like the Spirit, Dipsychus is entranced by the idea of coherence, except that his version is ruthlessly exclusionary rather than ruthlessly reductive. 'Life should be as the gondola!' becomes his refrain in the lengthy canal scene (1. 5. 255), 'In one unbroken passage borne / To closing night from opening morn!' (1. 5. 27-8). The iambic stress-pattern throws a desperate weight onto Dipsychus's 'should', but the regulating force of his metre is no more sustainable than his epistemology: as the Spirit protests, 'I'm deadly weary of your tune, / And half-ennuyé with the moon' (1. 5. 226-7). Dipsychus's demand for certain knowledge constitutes a refusal of the world in advance, because it defines the knowledge he so anxiously desires as not of this world, the celestial preserve of stars and sky. 
Cavell's insight suggests that Dipsychus's yearnings might be the twin, not the rival, of the dream-voice's sceptical assertions. This suggestion finds support in the text, for Dipsychus tacitly accepts the sceptical conclusions of his dream-tormentor, acknowledging his heavenly fancies as a screen for darker perceptions: 'O in our nook unknown unseen, / We'll hold our fancy like a screen / Us and the dreadful fact between' (1. 7. 50-2). And while critics have tended to read the dream utterances as a 'logical extension' of all the Spirit has said, in fact the Spirit is quick to dissociate himself from the dream's more metaphysically charged discourse: 'really, you owe some apology / For harping thus upon theology', he objects (1. 7. 132-3). ${ }^{49}$ Far from being a common-or-garden 'materialist' like the Spirit, the dream-voice aspires to the 'transcendently cynical' part Clough himself confessed to playing sometimes at society parties. ${ }^{50}$ This latter attitude is recognizable as a species of the 'allcorroding, all-dissolving scepticism' that Clough's erstwhile colleague at Oriel, John Henry Newman, considered endemic in mid-Victorian intellectual culture ${ }^{51}$ Dipsychus suggests that this attitude is beguiled by the very sense of certainty it pretends to despise.

In making this suggestion Clough extends and refines upon Emerson's argument in 'Montaigne'. Emerson had suggested that the 'materialist' treads a path towards 'disgust' through the 'indifferentism' of his Oxford gentleman ("“there's nothing new or true, - and no matter"'). Dipsychus plots a slightly different trajectory: by cutting Emerson's final clause and attributing the remainder of his words to Dipsychus's dream ('nothing's new and nothing's true') he makes the phrase sound less like the Spirit's insouciant 'common sense' and more like an echo to Dipsychus's passion for the absolute. Dipsychus's sense of disgust, his persistent fear of filth and pollution, is shown to thrive not on indifferentism but on fastidiousness (even if, as we saw earlier, this fastidiousness is sometimes performative). It is the 'materialist' Spirit, by contrast, who contests his horror of contamination: 
To use the undistorted light of the sun

Is not a crime; to look straight out upon

The big plain things that stare one in the face

Does not contaminate; to see pollutes not

What one must feel if one won't see, what is,

And will be too, howe'er we blink, and must

One way or other make itself observed.

Free walking's better than being led about; and

What will the blind man do, I wonder, if

Some one should cut the string of his dog?

These lines are among the strongest in Dipsychus, lending weight to the Epilogue's intriguing suggestion about the Spirit: that 'perhaps he wasn't a devil after all' ${ }^{52}$ When he urged Dipsychus to 'see things simply as they are' (2.3.168) a few scenes earlier, it was easy to dismiss this as a token of his narrow-minded knowingness: seeing things as they are turned out to mean adjusting one's vision to the cramped perspective of 'plain good common sense' (2. 3. 175), rather than some more exacting, Arnoldian demand for objectivity. Yet these later lines cannot be brushed aside as mere sophistry; their critique of blinkered vision identifies how both Dipsychus and the Spirit himself make experience hostage to their knowingness. The alternative proposed to such forms of avoidance is the Emersonian one of selfreliance: 'Free walking's better than being led about'. The conviction of this claim owes much to the passage's subtle command of rhythm: rather than the clinching and clenched predictability of the Spirit's usual hudibrastics, these lines ramify in volatile and unexpected ways, giving form to his profession of freedom in the tactful deployment of pauses, inversions, and extrametrical syllables. The nub of the Spirit's argument, 'To see pollutes not' — which hovers momentarily as an independent unit of sense — gains its force from the 
way it compresses the mounting rhetorical tension roused by the overrunning syntax and hammering monosyllables of the previous lines. As for Clough's curiously passive construction of seeing ('must / One way or other make itself observed'), this harbours an echo of Emerson's insistence on the 'perfect faith' owed to 'involuntary perceptions' in 'SelfReliance' ${ }^{53}$ To open one's eyes to such encounters is to break free from the shackles of the already known: to 'cast away' one's 'hoarded knowledge' that one might begin to 'know any thing rightly', as Emerson puts it in 'Circles' (189). The Spirit's prosody makes palpable this sense of bursting bonds, the crafty introduction of an extra beat at the end of line 134 priming a reversal of rhythm from rising iambs to tumbling dactyls and trochees, feet whose momentum instantly recalls the vigorous dactylic energy of Clough's Bothie. The culminating image of the blind man, meanwhile, is a further remembrance of 'Self-Reliance', in which Emerson had described 'conformity' as a game of 'blindman's-buff' (32).

The Emersonian imperative to 'look straight out' is one Clough returned to in a letter to Blanche, portraying it as a means of clearing the ramparts erected by knowingness: 'The plain rule in all matters is, not to think what you are thinking about the question, but to look straight out at the things and let them affect you; otherwise how can you judge at all? ${ }^{, 54}$ Instead of the peculiarly self-conscious activity of thinking what you are thinking, a cognitive regress like Dipsychus's desire to know his knowledge, Clough advocates a vulnerable mode of receptivity and encounter as the basis for judgement, like that which Emerson had advanced in 'Intellect': 'Our thinking is a pious reception ... We only open our senses, clear away as we can all obstruction from the fact, and suffer the intellect to see. ${ }^{55}$ Where Emerson closes the gap between seeing and thinking, Clough effects a parallel reconciliation between looking and judging; knowing, in both cases, is reinvented as a form of engagement rather than proprietorship. 
This is an ideal which Clough believed Emerson's writing did not always live up to, however. After meeting Emerson in person for the first time, Clough told Tom Arnold how pleased he was to find him 'much less Emersonian than his Essays. There is no dogmatism or arbitrariness or positiveness about him. ${ }^{56}$ Even in an essay like 'Montaigne' Emerson cannot resist the thundering injunction to 'let us know what we know for certain' (90), a summons which risks reinscribing the recursive knowingness which the same essay so gleefully explodes. Freedom from dogmatism, arbitrariness, and positiveness, by contrast, requires keeping the door open to the possibility of being gainsaid, cultivating an appetite for encounter — and resistance — that is as demanding as it is hospitable. Confronted with the failure of his quest for coherence, Dipsychus catches a glimmer of how it might be reimagined in these terms: 'Hints haunt me ever of a More beyond: / I am rebuked by a sense of the incomplete, / Of a completion over-soon assumed, / Of adding up too soon' (2. 4. 3942). If he cannot bring himself to disavow completion, Dipsychus finds that the gap between this ideal and his attempts to realize it can nonetheless be figured as tantalizing surplus as well as reproachful deficiency. His 'More beyond' may seem at first like a metaphysical makeshift, akin to his earlier proposal to 'Fix perfect homes in the unsubstantial sky, / And say, what is not, will be by-and-by' (1. 5. 71-2). Yet by rooting the problem firmly in terrestrial time, the following lines make it sound less like a theological convenience and more like an Emersonian intuition of the inexhaustibility of experience. Taking the measure of the world would then appear as an open-ended invitation rather than an exercise in futility. The use of such arithmetic, Dipsychus perceives, is precisely this ability to take a new account. As 'Spiritual Laws', one of those essays that first ignited Clough's enthusiasm for Emerson, had suggested, 'To make habitually a new estimate, - that is elevation'. 57

To ears still ringing with such exhortations, Arnold's chief complaint against Clough - that in his poetry he was 'ever learning, never coming to the knowledge of the 
truth' — might sound inadvertently gratifying. ${ }^{58}$ No critic seems to have recognized that this frequently cited remark is almost a direct quotation from the Tractarian Isaac Williams's influential 1838 treatise 'On Reserve in Communicating Religious Knowledge' (Tract $L X X X)$. It is a reference which is unlikely to have escaped Clough, since 1838 marked what Anthony Kenny has described as 'the high point' of Clough's undergraduate 'flirtation with Tractarianism'. ${ }^{59}$ Appealing to biblical and patristic example, Williams's tract argued for a wise discretion in the communication of religious truth, a doctrine referenced with contempt by the Spirit in Dipsychus ('You think half-showing, half concealing, / Is God's own method of revealing', 2. 1.31-2). Arnold's allusion suggests that, by declining to rest in the security of knowledge (however dimly perceived), Clough's poetry risked what Williams called the 'unsettledness and inconsistency' of 'religious enthusiasm', which he characterized as 'a state of ever learning, and never coming to the knowledge of the truth'. ${ }^{60}$ The wider context of Williams's remark is telling not only because the pejorative term 'enthusiasm', commonly levelled against Dissenters, ranges Clough with the Transcendentalist (and quondam Unitarian) Emerson against the Establishment, Anglican Arnold, but also because his supplementary charges glow with Emersonian resonance. It was Emerson, after all, who would write that 'A foolish consistency is the hobgoblin of little minds' ('Self-Reliance', 33) and who would warn, or rather promise, his readers that he would 'unsettle all things' ('Circles', 188). Such 'onward thinking' inflects Clough's impulse towards dissent, preeminently self-dissent, the notorious 'dialogue of the mind with itself' which Arnold repudiated in the 1853 'Preface' to his Poems and which has become a commonplace of Clough criticism. ${ }^{61}$ Yet Clough had pre-empted Arnold's critique in an unpublished essay written around the same time: though 'I cannot be in two places at once', he reasoned, 'shall I therefore refuse to visit them at different times? ${ }^{62}$ Emerson's admiration for how 'the mind goes antagonizing on' in 'Experience' (39) translates Arnold's notion of self-dialogue into a 
more positive register, no longer the pattern of helpless soliloquies but a model of alert, receptive, flexible intelligence, in flight from the captivity of knowingness.

\section{THE FROWARD CHAOS OF FUTURITY}

The desire not to let one's knowingness pre-empt one's experience makes a potent ally of the future, whose unknowability underwrites spacious notions of freedom and possibility in the present. Engagement with questions of futurity is not only crucial to Dipsychus but also the principal means by which Clough's conversation with Emerson is carried on beyond this poem. '[T]he coming only is sacred', declares Emerson in 'Circles' (189), and his dethronement of knowingness in 'Experience' is at the same time the enthronement of the future: 'I had fancied that the value of life lay in its inscrutable possibilities; in the fact that I never know, in addressing myself to a new individual, what may befall me', Emerson writes. 'Shall I preclude my future, by taking a high seat, and kindly adapting my conversation to the shape of heads?' (32). 'Self-Reliance', too, anchors its argument in the promise of futurity, decrying the misplaced reverence for one's past word or act that threatens to cripple 'selftrust' (33). 'But why should you keep your head over your shoulder?' it demands; 'Greatness appeals to the future' $(33,34)$. In the opening letter of Amours de Voyage, Clough's anti-hero Claude draws a similar lesson from Rome's sedimentary layers of material culture, under whose historic heft he feels 'buried' (1.38). In the same way, it is a 'blessing', he tells Eustace, 'to be rid, at least for a time, of / All one's friends and relations, - yourself (forgive me!) included,- - / All the assujettissement of having been what one has been' (1.28-30). Claude's savoursome French loanword is not mere hexametrical ostentation but carries a singular nuance. As a contemporary dictionary explained, assujettissement implied a habitual state of subjection to be distinguished from the more transitive subjugation implied by 
sujétion: the difference, it noted, was that between being under the yoke and dragging one's yoke ('Par l'assujettissement, nous sommes sous le joug; et par la sujétion, nous traînons notre joug'). ${ }^{63}$ To wish to be rid of one's assujettissement is therefore to aspire to nothing less than a change in being, as the rest of Claude's line suggests. His apparent tautology ('having been what one has been') is partly, of course, a way of avoiding describing what he has been, but it also captures the grammar of his predicament. It is the having been of what one has been that turns a simple statement of retrospect ('I was') into a testament to the past's jealous hold on the present; the perfect participle converts the knowledge of what one has been from an epistemological into an ontological question, raising the stakes of what it means to be knowing about oneself.

Not allowing the self to be terrorized by what it knows (or thinks it knows) about itself is a theme Emerson warms to in 'Circles'. The 'man and woman of seventy', he writes, 'assume to know all', yet such omniscience is self-enslaving: 'In nature every moment is new; the past is always swallowed and forgotten ... No love can be bound by oath or covenant to secure it against a higher love' (189). Claude, too, refuses to be bound by selfknowingness: 'Oh, I cancel, reject, disavow, and repudiate wholly / Every debt in this kind, disclaim every claim, and dishonour, / Yea, my own heart's own writing, my soul's own signature! Ah, no! / I will be free in this; you shall not, none shall, bind me' (3. 192-5). The passion of this protest lies in its appearance of breathless self-revision, the apparent crossings-out which dramatize the unchallengeable authority of the present moment: 'cancel' seems cancelled by 'reject', which seems rejected by 'disavow', and so forth. This selfrevising syntax is not limited to one passage but a distinguishing characteristic of Claude's voice; one could say that not knowing what he might say next is one of the things we know him by. 
When Claude later asks himself whether he would risk his own life for the English ladies in the event of a siege, he is unwilling to answer in advance: 'Really, who knows? ... Am I not free to attend for the ripe and indubious instinct?' $(2.67,84)$. Instinct - a word rich in Emersonian resonance-is put beyond doubt because it is beyond knowing, is the opposite of knowing. After waving Emerson off from Liverpool in July 1848, Clough committed to his diary the Emersonian advice 'to follow one's own fancy, the leading of one's heart \& the instinct of the inner sense'. ${ }^{64} \mathrm{~A}$ similar faith in 'a kind of impetus within, / Whose sole credentials were that trust itself' is the culminating statement of Clough's Adam and Eve, which he was writing in the same year. ${ }^{65}$ Such affirmations grant the future an authority unconstrained by any knowing in advance.

Yet elsewhere in Clough's poetry such faith in future instinct is engaged more critically. Dipsychus, for example, delivers an Emersonian lecture about instinct which he then proceeds to scrutinize:

Oh, it is great to do and know not what,

Nor let it e'er be known. The dashing stream

Stays not to pick his steps among the rocks,

Or let his water-breaks be chronicled.

And though the hunter looks before he leap,

'Tis instinct rather than a shaped-out thought

That lifts him his bold way. Then, instinct, hail;

And farewell hesitation.

These lines endorse Emerson's proposition that the alternative to knowing is being led by one's unknowable instincts, echoing 'Circles"' claim that 'The one thing which we seek with insatiable desire is to forget ourselves, to be surprised out of our propriety, to lose our 
sempiternal memory and to do something without knowing how or why' (190). Yet even before Dipsychus goes on to critique this reliance upon instinct, his choice of words suggests an implicit reservation about such unknowing action. If Emerson is audible in this passage, so too is King Lear on the verge of madness, in his words just before the storm: 'I will do such things_ - What they are yet I know not' ${ }^{66}$ Dipsychus's images of dashing water, rocks, and bold leaps bring to mind the tempest-tossed heath and Gloucester's blind, despairing urge to vault from the cliffs. Moreover, when Dipsychus produces Hotspur as a figure who embodies the life of instinct, the words he gives him ('To Horse, To Horse', 2. 3. 109) are in fact Lear's, as reported by Gloucester ('He calls to horse, but will I know not whither', 2. 2. 490). Yet if Lear haunts Dipsychus's speech in this way, are we to read this as a challenge to Emerson's celebration of unknowing action, suddenly exposed as uncomfortably close to madness, or as an Emersonian challenge to the determinism of allusion itself, a rejection of the idea that Lear's words have only one kind of import, one possible string of consequences? Dipsychus's ensuing critique of instinctive action, which maintains that such action is no longer possible at this stage in history, might be thrown back at him in a similar way. 'No, no', he asserts, 'The age of instinct has, it seems, gone by / And will not be forced back' (2. 3. 104-6). Dipsychus describes Napoleon as the last great representative of 'instinct' (2. 3. 45), echoing Emerson's account of him in Representative Men as a man of 'prompt invention' who 'took Occasion by the beard'. ${ }^{67}$ Yet it is perhaps Dipsychus's very conviction of the post-Napoleonic age's fallenness - his insistence that the modern individual is emptied of agency and left figuratively 'fiddling with a piston or a valve' (2.3.123) — that prevents Dipsychus himself from taking the initiative. If he is unable to act without knowing how or why, it is because he is prevented from doing so by his excessive knowingness about himself ('For nothing else we can be', he insists, 2. 3. 137). Or rather, his knowingness is a pretext for his passivity, a way of suppressing his fear of the future and of the unknown. As the 
psychoanalyst Jonathan Lear has written of Oedipus's knowingness, 'the stance of "already knowing" functions as a defense: if you already know, you do not need to find out' ${ }^{68}$

Claude, too, holds his knowing like a screen against the uncertainty of the future. 'Is it the calling of man to surrender his knowledge and insight,' he ponders, 'For the mere venture of what may, perhaps, be the virtuous action?' (2. 86-7). Claude's scornful rhetorical question may carry the ring of assurance, but his alliteration cuts across his reasoning, hinting that there might be virtue in venturing. Far from offering adventure, however, Claude imagines the future as fundamentally vulnerable and in need of his protection: 'Must we abandon the future', he rather abstractly asks, 'for fear of omitting the present[?]' (2. 90). By shrinking from action in the present, Claude claims to make room for the future and save it from any particular train of consequences. Yet this is effectively to lock down the future, to limit it to a frozen version of the present, as Claude's later exclamation lays bare: 'Ah, let me look, let me watch, let me wait, unhurried, unprompted! / Bid me not venture on aught that could alter or end what is present!' (2. 274-5). This is a fantasy which seeks to confine the future within the reassuring (Emerson would say the degrading) bounds of the knowable.

'And isn't our need for knowledge', asks Nietzsche in The Gay Science, 'the will to uncover among everything strange, unusual, and doubtful something which no longer unsettles us? ${ }^{69}$ Given Nietzsche's deep and enduring affinity with Emerson, it is admirable that his translator, Josefine Nauckhoff, catches the Emersonian note of his rhetoric here. ${ }^{70}$ 'People wish to be settled', 'Circles' observes; 'only in so far as they are unsettled is there any hope for them' (189). Emerson's meaning is double: only as far as people are unsettled may we presume to hold out hope for them, but also, more literally, only as far as they are unsettled is there any hope left for themselves. For if one is completely settled, one has nothing to hope towards. Claude's fear of the unsettling risks pinning him down in this hopeless situation, for all his talk of the freedom of the soul: 'There are two different kinds, I 
believe, of human attraction: / One which simply disturbs, unsettles, and makes you uneasy, / And another that poises, retains, and fixes and holds you. / I have no doubt, for myself, in giving my voice for the latter' (2. 264-7). Claude's preferred means of defending against the unsettling is that suggested by Nietzsche: 'Ah, did we really believe that the Present indeed is the Only! / Or through all transmutation, all shock and convulsion of passion, / Feel we could carry undimmed, unextinguished, the light of our knowledge!' (3. 114-16). If Claude recognizes that his fantasy of fixity is an impossible dream, that his present knowledge might be only a guttering flame, he chooses not to greet the unseen with a cheer but to focus on the one thing he does know for certain—namely, that he will die.

It is only knowledge of this 'certain release', this 'exit secure', he contends, that makes tolerable the cognitive dissonance between the binding vows of marriage and the slipperiness of the heart's affections (3. 120, 121); only 'with the terminus all but in prospect' will he condescend to 'Talk of eternal ties and marriages made in heaven' (3. 111-12). Focussing on the future in this way becomes a means of surviving the uncertainties of the present, a reversal of the Emersonian reverence for the future's ability to unsettle us. 'Shall we come out of it all, some day, as one does from a tunnel?' he wonders towards the end of the poem (5. 181). Claude's tunnel vision exposes the poverty of knowable futures: his knowingness allows him to imagine only a petrified present or the finality of death. As Emerson warns in 'Self-Reliance', in such circumstances knowing risks becoming a substitute for living: 'man ... does not live in the present, but with reverted eye laments the past, or, heedless of the riches that surround him, stands on tiptoe to foresee the future' (39).

When Claude does hazard a more imaginative conception of the future, it is to insist on the inevitable failure of all his amorous engagements. Claude tells Eustace he feels himself 
entering into all sorts of relations,

Tying I know not what ties, which, whatever they are, I know one thing,

Will, and must, woe is me, be one day painfully broken,-

Broken with painful remorses, with shrinkings of soul, and relentings,

Foolish delays, more foolish evasions, most foolish renewals.

Claude's rejection of any ties as binding has here mutated into a fatalistic determinism, as if every tie 'must' therefore be broken one way or another. His monomania-'I know one thing'—is a tell-tale symptom of knowingness, as Emerson suggests in 'Intellect': 'How wearisome the grammarian, the phrenologist, the political or religious fanatic, or indeed any possessed mortal whose balance is lost by the exaggeration of a single topic. It is incipient insanity. ${ }^{, 71}$ If Claude's self-revisions sometimes sound impatient for change, here their repetitiousness ('broken,_- / Broken'; 'Foolish ... foolish ... foolish') betrays a terrifying circularity of thought. Claude's nightmarish vision of the future culminates in 'renewals' that keep this cycle stuck in its grooves. David Shaw has observed that Amours is composed of 'expansive, circling hexameters ... often rolling over and over like huge ocean waves without actually advancing'; there is something monstrously circuitous about Claude's vision of the future, which by yielding to his knowing saps the present of life. ${ }^{72}$

Turning to Clough's wider oeuvre, it is striking how those poems which claim to disclose knowledge of the future are often among the weakest, and at their weakest in their endings. In a sense, then, it could be said that Claude's problem is often Clough's. Prophetic conclusions in Clough tend to shout very loud and ring very hollow; prophecy flings wide its jaws and eats the poetry: 'ye yet shall see / Each other, yet again shall meet. / Ah, joy! when, with the closing street, / Forgivingly at last ye greet!'; 'Thou shalt receive, thou shalt believe, / And thou shalt do, O Man!'; 'The Summum Pulchrum rests in heaven above ... Some day thou shalt it view'. ${ }^{73}$ In confronting these disappointing denouements, however, the qualities 
of Clough's best verse are rendered more visible. The effect of Clough's most famous poem, 'Say not the struggle naught availeth', may be dulled by familiarity, but set against this company one notes how the speaker shares in the addressee's thrill of anticipation rather than narrating it from a lofty height: 'In front the sun climbs slow, how slowly, / But westward, look, the land is bright' ${ }^{74}$ Most significant, however, is the way the hopeful expectation of this poem, unlike the others quoted, is sponsored by the unknowability of the future. Its metaphors imagine ways to challenge our knowing assumption that 'as things have been, things remain' (1. 4): the smoke of battle that limits our knowledge of what is going on in the field, the tide whose silent progress upstream escapes our notice, and the sunrise whose effects on the landscape we are liable to miss with our narrow angle of vision.

A few years after composing his elegy for Clough, Arnold confessed that he had left 'the whole prophet side' of his friend's character out of account — he had wanted to write a pastoral idyll, to 'deal again with that Cumner country', he told Shairp, and prophets do not belong in pastoral idylls. ${ }^{75}$ What 'Say not' demonstrates is that prophecy is more than a matter of prognostication, and that if the poet's role is, as Emerson proposed, 'an office of announcement and affirming', one of the things poetry may affirm in a culture of knowingness is the value of not knowing. ${ }^{76}$ This value is at the heart of Clough's lyric 'Where lies the land to which the ship would go?', in which Clough exchanges the inquisitive perspective of Wordsworth's quayside observer in his sonnet of a similar title ('Where lies the land to which yon Ship must go?') for the ignorance of the ship's crew. ${ }^{77}$ 'Where lies the land to which the ship would go? / Far, far ahead, is all her seamen know. / And where the land she travels from? Away, / Far, far behind, is all that they can say' ${ }^{78}$ Simple yet hauntingly effective, the Tennysonian repetitions of the second and fourth lines push past and future away into equal and opposite spheres of unknowing, expanding the experience - and the significance — of the present, while their substitution of spondees for iambs 
correspondingly extends the time taken to voice these lines. The seamen's not knowing whence and whither they are voyaged is ambiguously pitched: on a first reading, the lines seem plangent, as if the sailors are sadly reconciled to their ignorance. Yet the central stanzas take advantage of this uncertainty to spring a surprise, revealing the crew's not knowing their destination, and forgetfulness about their departure, as a source of excitement and pride. The poem welcomes the carefree leisure this purchases, allowing them the opportunity to pace arm in arm along the deck, enjoying the 'foaming wake far widening as we go' (1l. 6, 8); still more does it welcome the opportunities to 'fight with wind and wave' on stormy nights (1. 10)_ 'The dripping sailor on the reeling mast / Exults to bear, and scorns to wish it past' (11. 11-12). The mariners' splendid life exists outside of onshore time, in an idealized realm without knowledge of either past or future, an unknowing which sponsors their delicious pleasures and their highwire daring.

Clough had originally thought of calling the poem 'Mari Magno', the title he later chose for his Chaucerian collection of 'Tales on Board' ${ }^{79}$ As Kenny notes, this phrase "echoes a famous passage of Lucretius, beginning "Suave mari magno", which describes the pleasure that watching ships battling with the elements at sea can give to someone safe on shore', yet it acquires profoundly ironic overtones in the context of the lyric. ${ }^{80}$ Lucretius had intended his image as a metaphor for the consolations of philosophy, its serene sanctuaries fortified by the teachings of the wise ('edita doctrina sapientum templa serena'). ${ }^{81}$ Yet in Clough's poem the wisdomless life on the wave is something dwellers on terra firma can only envy, beached on the headland of their knowledge. A manuscript draft of the poem, now in the Bodleian Library, is written on the reverse of one of Clough's unpublished 'Letters of Parepidemus', written for an American magazine onboard the ship Canada in 1852. 'We did come from somewhere', Clough wrote, 'we are going some whither; but really it is an effort to call that to mind. ${ }^{82}$ Whereas Carlyle's Latter-Day Pamphlets of 1850 declared that 'It is a 
Time to make the dullest man consider; and ask himself, Whence he came? Whither he is bound?', Emerson's 1841 essay 'The Over-Soul' had cautioned, 'Do not require a description of the countries towards which you sail ... For the soul is true to itself, and the man in whom it is shed abroad cannot wander from the present, which is infinite, to a future which would be finite. ${ }^{83}$ Clough's poem offers a vision of this ideal, lyricizing as well as literalizing Emerson's affirmation in 'Circles' that "“A man ... never rises so high as when he knows not whither he is going"' (190).

It is therefore a little ironic that Emerson should have criticized the 'baulking end or no end' of Amours de Voyage, in which Mary and Claude announce their intentions to set out for England and Egypt respectively. For baulking ends-whether in the sense of termini or preconceived objectives — might be considered an eminently Emersonian activity. As 'Nature' has it, 'Every end is prospective of some other end, which is also temporary; a round and final success nowhere. ${ }^{84}$ In Amours, Dipsychus, and other poems, Clough puts in question the desirability of a round and final success, testing Claude's nineteenth-century cliché—'When we know, we are happy' (5. 201)—to breaking point. ${ }^{85}$ As in Emerson's essays, knowing in Clough's poetry turns out very often to be a trap: a blasphemy against the future, the sabotage of hope. If, as his tutor Benjamin Jowett once remarked, Clough had 'a kind of faith in knowing nothing', this was not, as so many of his contemporaries and subsequent critics have believed, the paralysed resignation of a 'Too quick despairer', but the natural allegiance of one for whom, like Emerson, there is no knowing beforehand. ${ }^{86}$ 


\section{Acknowledgment}

I am grateful to the Arts and Humanities Research Council and All Souls College, Oxford for funding my doctoral studies, and to my supervisor, Professor Matthew Bevis, for his generous support and advice.

\footnotetext{
${ }^{1}$ Quoted in Horace Traubel, With Walt Whitman in Camden, vol. 8, ed. Jeanne Chapman and Robert MacIsaac (Oregon House, CA, 1996), 272.

${ }^{2}$ Ralph Waldo Emerson, 'Montaigne, or the Skeptic', in Representative Men: Seven Lectures, ed. Wallace E. Williams and Douglas Emory Wilson, The Collected Works of Ralph Waldo Emerson, vol. 4 (Cambridge, MA, 1987), 83-106, 88. Further references given in the text.
}

${ }^{3}$ See The Journals and Miscellaneous Notebooks of Ralph Waldo Emerson, vol. 10: 1847-1848, ed. Merton M. Sealts, Jr. (Cambridge, MA, 1973), 246, 282.

${ }^{4}$ See Arthur Hugh Clough to Emerson, 22 July 1850, in The Correspondence of Arthur Hugh Clough, ed. F. H. Mulhauser, 2 vols (Oxford, 1957), 1. 284.

${ }^{5}$ Clough, Dipsychus and the Spirit, 1. 7. 106-7, in Clough: Selected Poems, ed. J. P. Phelan (London, 1995), 155-234, 195. Further references given in the text.

${ }^{6}$ Emerson, 'Experience', in Essays: Second Series, ed. Joseph Slater, Alfred R. Ferguson, and Jean Ferguson Carr, The Collected Works of Ralph Waldo Emerson, vol. 3 (Cambridge, MA, 1983), 25-50, 31. Further references given in the text. For a more positive reading of knowingness as 'the glue of social discourse', see Simon Goldhill, ‘On Knowingness', Critical Inquiry, 32 (2006), 708-23, 722.

7 'Our Music Halls', Tinsley’s Magazine, 4 (1869), 216-23, 219, 218. See also Peter Bailey, 'Conspiracies of Meaning: Music-Hall and the Knowingness of Popular Culture', Past \& Present, 144 (1994), 138-70.

${ }^{8}$ William Hazlitt, 'On Londoners and Country People', in The Selected Writings of William Hazlitt, vol. 8: The Plain Speaker, ed. Duncan Wu (London, 1998), 61-70, 67, 65.

${ }^{9}$ See 'knowing one, $n$.', OED Online (pubd November 2010), accessed 1 June 2019; 'knowing, adj.', 4b, OED Online (pubd November 2010), accessed 1 June 2019.

${ }^{10}$ See Charles Dickens, Oliver Twist, ed. Kathleen Tillotson (Oxford, 1998), 10; David Copperfield, ed. Nina Burgis (Oxford, 2008), 319; William Makepeace Thackeray, The History of Pendennis, ed. John Sutherland (Oxford, 1994), 228.

${ }^{11}$ Edith Hall, 'The Aesopic in Aristophanes', in Emmanuela Bakola, Lucia Prauscello, and Maria Telò (eds), Greek Comedy and the Discourse of the Genres (Cambridge, 2013), 277-97, 283.

${ }^{12}$ George Eliot to Eugène Bodichon, 12 May 1863, in The George Eliot Letters, vol. 4: 1862-1868, ed. Gordon S. Haight (London, 1956), 85.

13 Thomas Carlyle, 'The Hero as King', in On Heroes, Hero-Worship and the Heroic in History, ed. H. D. Traill (London, 1897), 196-244, 227, 215; Carlyle, Wilhelm Meister's Apprenticeship and Travels, 2 vols, ed. H. D. Traill (London, 1899), 2. 183. 
14 'know-it-all, $n$. and adj.', A, OED Online (pubd online November 2010), accessed 1 June 2019; 'know, v.', P34, OED Online (pubd online November 2010), accessed 1 June 2019.

15 'sciolist, n.', OED Online (pubd online March 2014), accessed 1 June 2019.

${ }^{16}$ See The Journals and Miscellaneous Notebooks of Ralph Waldo Emerson, vol. 13: 1852-1855, ed. Ralph H.

Orth and Alfred R. Ferguson (Cambridge, MA, 1977), 271.

${ }^{17}$ Samuel Taylor Coleridge, 'Lectures on the Principles of Judgement, Culture, and European Literature:

Lecture 9', in Lectures 1808-1819 On Literature, 2 vols, ed. R. A Foakes, The Collected Works of Samuel Taylor Coleridge, vol. 5 (Princeton, NJ, 1987), 2. 167-82, 174.

${ }^{18}$ Clough, 'Recent English Poetry', North American Review, 77 (1853), 1-30, 3.

${ }^{19}$ Richard Poirier, Poetry and Pragmatism (Cambridge, MA, 1992), 53.

${ }^{20}$ Alexis de Tocqueville, Democracy in America, tr. Arthur Goldhammer (New York, NY, 2004), 484.

${ }^{21}$ John Campbell Shairp, Aspects of Poetry: Being Lectures Delivered at Oxford (Boston, MA, 1881), 431.

${ }^{22}$ Emerson, 'Circles', in Essays: First Series, ed. Joseph Slater, Alfred R. Ferguson, and Jean Ferguson Carr, The Collected Works of Ralph Waldo Emerson, vol. 2 (Cambridge, MA, 1979), 177-90, 182. Further references given in the text.

${ }^{23}$ Clough, 'Paper on Religion', in Selected Prose Works of Arthur Hugh Clough, ed. Buckner R. Trawick (Tuscaloosa, AL, 1964), 287-9, 288. Trawick suggests this dating at 338.

${ }^{24}$ Walter Bagehot, 'Mr Clough's Poems', in National Review, 13 (October 1862), 310-26, 326.

${ }^{25}$ Isobel Armstrong, Arthur Hugh Clough (London, 1962), 12; John Addington Symonds, ‘Arthur Hugh Clough', Fortnightly Review, 24 (1868), 589-617, 605; George Saintsbury, A History of Nineteenth-Century Literature 1780-1900 (London, 1908), 317. See also Edmund Gosse's 1921 assessment of Clough as 'a derelict schooner' for whom life 'all petered out' and Katharine Chorley's Freud-inflected account of his 'deep-seated fear of committing oneself'. See Gosse, 'Clough', in Books on the Table (London, 1921), 127-36, 132, 130, and Chorley, Arthur Hugh Clough: The Uncommitted Mind (Oxford, 1962), 360.

${ }^{26}$ See Paul Giles, 'Arthur Hugh Clough and the Poetics of Dissent', in Atlantic Republic: The American Tradition in English Literature (Oxford, 2006), 112-34; Adam Phillips, 'Arthur Hugh Clough: The Reception and Conception of Amours de Voyage', in Matthew Bevis (ed.), The Oxford Handbook of Victorian Poetry (Oxford, 2013), 385-99; Evelyn Greenberger, Arthur Hugh Clough: The Growth of a Poet's Mind (Cambridge, MA, 1970), 105.

${ }^{27}$ During these years Clough wrote the Ambarvalia lyrics, Adam and Eve, The Bothie of Tober-na-Vuolich, Amours de Voyage and Dipsychus. Following his return from the United States in 1853, Clough's poetic output was limited to revisions of the latter two poems and the short Mari Magno tales composed during his final months.

${ }^{28}$ Giles, 'Clough and the Poetics of Dissent', 120; Anna Barton, 'Liberal Republicanism: Clough, Barrett Browning and Swinburne', in Nineteenth-Century Poetry and Liberal Thought (London, 2017), 179-232, 186. ${ }^{29}$ Gregory Tate, 'Clough, Arnold, and the Dialogue of the Mind', in The Poet's Mind: The Psychology of Victorian Poetry 1830-1870 (Oxford, 2012), 59-90, 59.

${ }^{30}$ Tate, 'Clough, Arnold, and the Dialogue of the Mind', 65. For the same reason Emersonian knowingness sits slightly aslant to that which Andrew H. Miller identifies in a wonderfully evocative essay on John Henry Newman. Miller explicitly defines 'knowingness' as a 'denial of skepticism', though he does not historicize 
either term. See 'Responsiveness, Knowingness, and John Henry Newman', in The Burdens of Perfection: On Ethics and Reading in Nineteenth-Century British Literature (Ithaca, NY, 2008), 142-61, 142.

${ }^{31}$ See Anthony Kenny, Arthur Hugh Clough: A Poet's Life (London, 2005), 64, 125-6, 134.

${ }^{32}$ Clough to Emerson, 26 November 1847, in Correspondence, 1. 187; Emerson to Blanche Clough, 14 January 1862, in The Selected Letters of Ralph Waldo Emerson, ed. Joel Myerson (New York, NY, 1997), 408.

${ }^{33}$ See Kenny, Life, 234-64.

${ }^{34}$ See Kenny, Life, 129-30.

${ }^{35}$ Emerson, 22 December 1848, in The Journals and Miscellaneous Notebooks of Ralph Waldo Emerson, vol. 11: 1848-1851, ed. A. W. Plumstead and William H. Gilman (Cambridge, MA, 1975), 64.

${ }^{36}$ Emerson, Journals, 11. 64.

${ }^{37}$ See 'résistance', Collins Robert French Dictionary, $9^{\text {th }}$ edn (Glasgow, 2010), 832.

${ }^{38}$ Emerson, 'The Over-Soul', in Essays: First Series, 157-76, 172. For Clough's reading, see The Oxford

Diaries of Arthur Hugh Clough, ed. Anthony Kenny, $2^{\text {nd }}$ edn (Oxford, 2002), 182.

${ }^{39}$ Emerson, 'Character', in Essays: Second Series, 51-68, 58-9.

${ }^{40}$ Clough, The Bothie of Tober-na-Vuolich, 9. 50, in The Poems of Arthur Hugh Clough, ed. F. L. Mulhauser, $2^{\text {nd }}$ edn (Oxford, 1974), 44-93, 89.

${ }^{41}$ Clough to Tom Arnold, 29 October 1849, in Correspondence, 1. 274.

${ }^{42}$ Emerson, 'The Transcendentalist', in Nature, Addresses, and Lectures, ed. Robert E. Spiller, The Collected Works of Ralph Waldo Emerson, vol. 1 (Cambridge, MA, 1971), 201-16, 213.

${ }^{43}$ See Clough, Selected Poems, 157. The Spirit also confides that 'Mephistopheles' is one of his names in the final draft at 2. 7. 58 .

${ }^{44}$ Emerson, 'Goethe, or the Writer', in Representative Men, 149-68, 159.

${ }^{45}$ Carlyle, 'Goethe's Helena', in Critical and Miscellaneous Essays, ed. H. D. Traill, 5 vols (1899), 1. 146-97, 157.

${ }^{46}$ As Greenberger notes, 'Clough must have been familiar with both Emerson's first and second series of essays by 1845, when Anne, whose reading Clough guided, was studying the second series' (The Growth of a Poet's Mind, 104-5). Among Clough's papers in the Bodleian is an inventory of his library at his death, which includes 'Emerson's Essays', ‘Emerson's Poems’, ‘Emerson's English Traits', and 'Emerson's Representative Men' (Oxford, Bodleian Library, MS Eng. misc. c. 359, f. 155).

${ }^{47}$ Coleridge, 'Lectures', 2. 174.

${ }^{48}$ Stanley Cavell, Disowning Knowledge in Seven Plays of Shakespeare (Cambridge, 2003), 12.

${ }^{49}$ For the standard view quoted here, see Mark Storey, 'The Sound of Distant Laughter: Clough', in Poetry and Humour from Cowper to Clough (London, 1979), 145-78, 172.

${ }^{50}$ Quoted from his unpublished letter to Blanche Smith, 21 January 1852, Oxford, Bodleian Library, MS Eng. Lett. e. 77, f. $65^{\mathrm{v}}$ (emphasis mine).

${ }^{51}$ John Henry Newman, Apologia Pro Vita Sua, ed. Ian Ker (London, 1994), 218.

${ }^{52}$ Clough, Selected Poems, 231.

${ }^{53}$ Emerson, 'Self-Reliance', in Essays: First Series, 25-52, 37. Further references given in the text. 
${ }^{54}$ Clough to Blanche Smith, 9 March 1853, in Letters and Remains of Arthur Hugh Clough (London, 1865), 250-1. Compare also Claude's determination, in Amours de Voyage, to 'look straight out, see things, not try to evade them', 5. 100, in The Poems, 94-133, 129. Further references given in the text.

${ }^{55}$ Emerson, 'Intellect', in Essays: First Series, 191-206, 195.

${ }^{56}$ Clough to Tom Arnold, 16 July 1848, in Correspondence, 1. 216.

${ }^{57}$ Emerson, 'Spiritual Laws', in Essays: First Series, 75-96, 83.

${ }^{58}$ Matthew Arnold to Clough, 30 November 1853, in The Letters of Matthew Arnold, ed. Cecil Y. Lang, 6 vols (Charlottesville, VA, 1996), 1. 282.

${ }^{59}$ Kenny, Life, 44.

${ }^{60}$ Isaac Williams, 'On Reserve in Communicating Religious Knowledge', in Tracts for the Times, vol. 4 (London, 1840), 1-82, 57.

${ }^{61}$ Emerson, 'History', in Essays: First Series, 1-24, 14; Arnold, 'Preface to First Edition of Poems (1853)', in The Complete Prose Works of Matthew Arnold, vol. 1, ed. R. H. Super (Ann Arbor, MI, 1960), 1-15, 1.

${ }^{62}$ Clough, 'Notes on the Religious Tradition', in Selected Prose, 289-96, 293. Based on the manuscript source, Trawick dates the essay to $1852-53$ (338).

${ }^{63}$ Dictionnaire Universel des Synonymes de la Langue Française, 2 vols (Paris, 1839), 1. 71.

${ }^{64}$ Clough, 15 July 1848, Oxford Diaries, 251.

${ }^{65}$ Clough, Adam and Eve, 14. 44-5, in The Poems, 165-87, 187.

${ }^{66}$ William Shakespeare, King Lear, 2. 2. 472-3, in The Arden Shakespeare: Complete Works, ed. Richard Proudfoot et al. (London, 2013), 650. Further references given in the text.

${ }^{67}$ Emerson, 'Napoleon, or the Man of the World', in Representative Men, 127-48, 141.

${ }^{68}$ Jonathan Lear, 'Knowingness and Abandonment: An Oedipus for Our Time', in Open Minded: Working Out the Logic of the Soul (Cambridge, MA, 1998), 33-55, 34.

${ }^{69}$ Friedrich Nietzsche, The Gay Science, 5. 355, ed. Bernard Williams et al., tr. Josefine Nauckhoff (Cambridge, 2001), 214.

${ }^{70}$ See Mason Golden, 'Emerson-Exemplar: Friedrich Nietzsche's Emerson Marginalia', Journal of Nietzsche Studies, 44 (2013), 398-431.

${ }^{71}$ Emerson, 'Intellect', 200-1.

${ }^{72}$ W. David Shaw, Victorians and Mystery: Crises of Representation (Ithaca, NY, 1990), 175.

${ }^{73}$ Clough, 'Sic Itur', 11. 18-21, in The Poems, 8-9, 9; 'The New Sinai', 11. 125-6, in The Poems, 17-20, 20; 'Blank Misgivings of a Creature moving about in Worlds not realised', 11. 17, 20, in The Poems, 28-34, 34. ${ }^{74}$ Clough, 'Say not the struggle naught availeth', 11. 15-16, in The Poems, 206. Further references given in the text.

75 Arnold to John Campbell Shairp, 12 April 1866, in Letters, 3. 35.

${ }^{76}$ The $O E D$ distinguishes between prophecy in the sense of 'inspired speech', and prophecy in the narrower sense of prognostication ('prophecy, $n$.', $1 \mathrm{~b}$ and 2a, OED Online (pubd online June 2007), accessed 1 June 2019); Emerson, 'The Poet', in Essays: Second Series, 1-24, 8.

${ }^{77}$ William Wordsworth, 'Where lies the Land to which yon Ship must go?', in Poems, in two Volumes, and Other Poems, 1800-1807, ed. Jared Curtis (Ithaca, NY, 1983), 137-8. 
${ }^{78}$ Clough, 'Where lies the land to which the ship would go?', 11. 1-4, also 13-16, in The Poems, 342. Further references given in the text.

${ }^{79}$ See Mulhauser's note in The Poems, 750.

${ }^{80}$ Kenny, Life, 276-7.

${ }^{81}$ Lucretius, On the Nature of Things, 2.8, tr. W. H. D. Rouse, revised by Martin F. Smith (Cambridge, MA, 1924, 2006), 94.

${ }^{82}$ Oxford, Bodleian Library, MS Eng. misc. d. 512 f. $57^{\mathrm{v}}$.

${ }^{83}$ Carlyle, 'The Present Time', in Latter-Day Pamphlets, ed. H. D. Traill (London, 1899), 1-47, 2; Emerson, 'The Over-Soul', 168.

${ }^{84}$ Emerson, 'Nature', in Essays: Second Series, 97-114, 110.

${ }^{85}$ See, for instance, the Revd Thomas Dick's pronouncement that the 'rapid progress' and 'general diffusion' of knowledge portended 'a new and happier world', in On the Improvement of Society by the Diffusion of Knowledge (New York, NY, 1833), 27. For a wider discussion of the high hopes entertained about knowledge in the Victorian period, see Alice Jenkins, Space and the 'March of Mind': Literature and the Physical Sciences in Britain, 1815-1850 (Oxford, 2007) and Alan Rauch, Useful Knowledge: The Victorians, Morality, and the March of Intellect (Durham, NC, 2001).

${ }^{86}$ Benjamin Jowett to Miss Elliot, 2 February 1862, in Letters of Benjamin Jowett, ed. Evelyn Abbott and Lewis Campbell (London, 1899), 177; Arnold, 'Thyrsis', 1. 61, in The Poems of Matthew Arnold, ed. Kenneth Allott (London, 1965), 496-507, 501. 